\title{
The Self and the Other in "The Land of Dreams"
}

\author{
Sura M. Khrais \\ Al Balqa Applied University, Amman, Jordan \\ Hana A. Daana \\ Al Balqa Applied University, Amman, Jordan
}

\begin{abstract}
This paper is a study of the post-colonial polarity of the Self/the Other in Hanan Al Shaykh's short story "The Land of Dreams". It investigates the sub-textual tensions between her admiration of the European model (the Self) and her status as an Arab writer representing the Other. Thus, Al Shaykh presents a prejudiced text in which the Other is misrepresented and rather stereotypically portrayed. While the Self is civilised and a savior-like figure, the Other (Yemini men and women) is primitive, superstitious and ignorant. Furthermore, the researcher will show that what seems to be a meaningful connection across the racial line where the Self (Ingrid; the civilised European) and the Other (Yemini people) find a contact zone is no more than an illogical oversimplification of the relationship. While Hanan Al Shaykh introduces this model of racial liberation through unification of the Self and the Other, the question remains to what extent would that relationship sustain the pressures of the primitive culture of the Other? Indeed, Al Shaykh tends to simplify and generalise the relationship to the point of producing romantic and idealised images of a human contact beyond cultural and racial gaps, which strikes the reader as naïve and unrealistic.
\end{abstract}

Index Terms - post-colonial polarities, the Self and Other, racial reconciliation, cultural and racial gaps.

\section{INTRODUCTION}

Despite the fact that Hanan Al Shaykh is an Arab writer, her admiration of the European model motivates her to produce a prejudiced literary text which becomes a site of highly effective instrumentality for the determination of the Muslim Arab character by fixing him/her under the sign of the Other. Al Shaykh's discourse fails to describe the Other faithfully. It is the goal of this study to recognise how the binarisms of colonial discourse- (the Self/the Other, the Civilised/the primitive, the educated/the ignorant)- operate in this story through an analysis of the main character of Ingrid the Danish missionary on the one hand, and the characters of Yemini men and women on the other hand. Consequently, the researcher hopes to promote an active reading which, to borrow JanMohamed's words, "makes these texts available for rewriting and subversion" (1985, p. 65).

\section{DISCUSSION}

\section{A. Myths and Common Assumptions about the Other}

"The Land of Dreams" tells the story of Ingrid the European missionary who leaves Denmark to live in Yemen. She believes that her mission is inspired by a vision that had come to her one evening. The voice of Virgin Mary called her, "Go to the ends of the earth, to a land where they haven't seen me. lift the darkness from their eyes. Tell them about me, then let them choose" (LD1, p. 84). Ingrid's relationship with Mahyoub, her Yemini driver and Souad's brother, develops into a marriage proposal. The closing scene of the story shows Ingrid wearing Souad's wedding dress as she is surrounded by many Yemini women.

Myths about the Other (Yemini men and women) are impeded in the sub-text of the story. In addition, common assumptions about the behaviour and qualities of Muslims and Arabs are evident. For example, Yemini men are portrayed as lazy and have no respect for time (LD, p.47), they are childish rather than cunning (LD, p. 52), and they are sexually frustrated (LD, p. 57). They are dirty and even disgusting shopkeepers. The male hand which scoops up olives and cuts cheese, finds its way, finally, to the shopkeeper's nose (LD, p. 61). Furthermore, Yemini men are seen as leading a double life divided between a wife and the pleasures of storytelling and chatting with beautiful Ingrid who has a long blonde hair. Usually when they listen to Ingrid's stories, "they became like children...paying rapt attention and easily affected by what they heard" (LD, p. 66). In addition, they are cruel towards their own flesh and blood. When Souad (Mahyoub's sister) falls ill and nearly dies of dehydration, Mahyoub shows no concern about her illness. Ingrid almost drags him out of his bed and forces him to take Souad to the hospital (LD, p. 70-1). Ingrid justifies his "cool indifference" that "if the sick person was a woman, it mattered less if she lived or died" (LD, p.73). Ingrid reaches that conclusion after she visits the graveyard and notices that women have one headstone while men two. Such an action opposes the teachings of Islam; it is a heresy. Thus, the whole remark sounds trivial.

\footnotetext{
1 "Land of Dreams" is identified in this paper by the abbreviated form (LD). The researcher.
} 
On the other hand, lack of hygiene, superstitious way of thinking, primitive beliefs and ways of living on the part of Yemini women are presented as a norm. Female villagers believe that not only their men, but also their animals are attracted to Ingrid's "strange colouring" (LD, p. 60). "Iftikar swore that her cow never took its eyes off Ingrid....and Husniyya too reported that her chickens were rooted to the spot in Ingrid's presence and the cock crowed at odd times of day" (LD, p.60). An old Yemini woman believes that "foreigners' wombs have stones in them. She [Ingrid] will be in labor for a year. Their kids have such huge heads" (LD, p. 63). Souad believes that her mother's soul has not rested in peace because Mahyoub has not married yet and for that her bones "are being curled up in a tense ball, rattling and shaking" (LD, p. 73). Furthermore, comparing women who emerge from their houses to welcome Ingrid to "rabbits [coming] from their burrows" (LD, p. 61) and to "kebabs on skewers made up of meat and vegetables of all shapes and sizes and colours" (LD, p. 81) as they gather inside one room in Souad's house is dehumanising. The vulgarity of the comparison is equally shocking. Also, those women are portrayed as bad mothers whose children are dirty, their hair matted with dust, their feet are black, their faces marked by various skin diseases (LD, p. 64).

To add, Yemeni female characters are portrayed as naïve and clumsy, so they are "suitable territory in which to sow the first seeds" of Ingrid's mission (LD, p. 48). However, Ingrid comes to learn soon enough that it is risky to talk to the women about the Bible. She must approach men first as it is "for the men to discuss things with her and then talk to their women" (LD, p. 60). Depriving women of freedom of thought and introducing them as mere puppets in the hands of their men who pull the strings, is shocking. Yemini women are depicted as being doubly burdened for being the silenced Other in a patriarchal society. None of the female characters not even Souad, the only educated Yemini woman in the story, is given an independent mature voice. None of them is able to construct a "speaking position" or an "effective voice" 2 clearly and unproblematically audible above the persistent male voices. Unfortunately, Al Shaykh does not introduce a rebellious female model whose sole wish is to break out of the shackles of the dominant.

\section{B. The Self: the Savior Figure}

Thus, the image of Other in Al Shaykh's story reminds us of the image of the colonised in colonialist texts where the colonised is portrayed as a racially degenerate population that is assigned a fixed position as the passive object of discursive domination (Bhabha, 1985, p. 151). In fact, the stereotypical depiction of the Other in the story is very clear. While poverty characterises the life of the Other, material wealth is a keynote of the Self's lifestyle. When Ingrid returns from Denmark, she brings gifts to Yemini women which she believes to be "Far more important items" such as a sewing machine, a sterilizer for babies' bottles, boxes of tools, second-hand cooking pots and matches (LD, p. 50). Such items suggest a pathetic degeneration of the life of Yemini people and introduce Ingrid as a saviour who brings civilization to those poor villagers who are in need of simple tools of survival. While they are ignorant about what is good for them, Ingrid is the superior European who knows what is best for Yemini people. She urges them not to be satisfied, not to surrender to their fate. She encourages secondary-school pupils to go to university and farmers to grow crops they haven't tried before (LD, p. 53).

\section{The Other: An Exaggerated Inferiority}

In addition, the incident of the veiled Yemini woman holding a cloth bag in the local market reveals how Yemini characters are dramatized as backward people and not checked by any inhibition of civilisation. When invited by Ingrid to join her for a cup of tea, the poor Yemini woman's eyes were open in wonder and amazement. When the Yemini woman enters Ingrid's house, the earlier stops in front of the mirror and examines her reflection in amazement as if for the first time. Next, she goes over and pats the sofa, picks up an ashtray and views it from all angles, and feels the curtains. Then she goes into the bedroom and sits on the bed and bounces up and down like a child. When Ingrid hurries to fetch the woman a picture of crucified Christ, "the woman drew her breath in sharply, putting a hand up to her mouth, but her attention was distracted by the knitted tea cosy" (LD, p. 49). Apparently, the woman finds it strange that a teapot should have a cover at all. Clearly, the supposed inferiority of the Other is exaggerated to the point of disbelief. AlShaykh never portrays the Other as an authentic character.

\section{Racial Reconciliation: A Nä̈ve Model}

On the other hand, the relationship which develops between Ingrid and Mahyoub does not celebrate the authenticity of the margin; a feature usually found in postcolonial texts. It is Mahyoub's only way to escape his ugly reality. Ingrid is his ticket out and English is a passport to a better life (LD, p. 53). "He was clinging to her as if she were a life preserver, trying love as a way to escape to Europe" (LD, P.58). Thus, a relationship across the racial bar functions as a reliable signifier of liberation from the primitive life in Yemen. While racial integration does not usually imply an oppression of the Other but his/her preservation, Mahyoub is willing to accept dissolution of his native identity into that of his beloved (the Self) by abandoning his homeland and his mother tongue. He welcomes assimilation and self-denial by giving up his indigenous identity. Mahyoub represents the usual ambition of the Other to imitate that attractive model (the Self). In The Wretched of the Earth (1961) Frantz Fanon shows that the colonial project is to depict native towns as

\footnotetext{
${ }^{2}$ In her essay, "Can the Subaltern speak?" Gyatri Spivak is concerned to articulate what she sees as the difficulties and contradictions involved in constructing a "speaking position" for the subaltern. [Spivak, 1988, p.26,28].
} 
places which remind the native of his daily oppression. These are crowded villages where people live and die quite insignificantly. The Other who lives in these villages is full of envy and anger as he dreams of possessing what the Self possesses (Fanon, p.30). Al Shaykh shows a degree of simplification which extends to a tendency to romanticise and idealise the relationship between the Self and the Other. We are told that Mahyoub has been "head over heels in love with Ingrid since the moment he first saw her" (LD, P.86) though he discusses the subject of emigration frequently. Souad, Mahyoub's sister, has told Ingrid's fortune in her coffee grounds: "You will marry one of us and forget your ideas and your stories" (LD, p. 86). The romantic image of the possibility of a human contact unqualified by race, cultural or class gaps, and uninfluenced by religious differences, strikes the reader as representing, in a touching naïve fashion, a momentary.

However, the love relationship between the young Yemini man and the European heroine which develops to a marriage proposal is an attempt to introduce a model of a hybrid relationship between the Self and the Other. Hybridity usually allows a development of new anti-monolithic models of cultural growth and exchange while highlighting the distinctive aspects of the culture of the Other. Chinua Achebe (1973) views cross-fertilization as a fruitful metaphor of a dialogic process of recovery which develops between the past (the colonial) and the present (the postcolonial). So, does Al Shaykh introduce an optimistic model of idealised racial reconciliation which develops into a racial marriage? Can the worlds of the Self and the Other impinge on a level of equality? These and other questions are to be answered within the body of this paper.

\section{E. Indigenization}

Now, let's discuss the Self's efforts to develop a relationship not only with Mahyoub, but also the whole Yemini society. In an attempt to win acceptance of the Yemini society so that her religious mission becomes much easier, Ingrid puts on a scarf to cover her blond hair despite Mahyoub's objection who believes she doesn't have to since she isn't a Yemini, or even a Muslim (LD, p. 51). Only there in Yemen, "she always had to be sure that her clothes were suitable: that they had long sleeves, didn't show her cleavage, didn't cling to her body, and covered her knees" (LD, p. 45). Furthermore, she realises her need to learn Arabic and try "understand the culture of the country" (LD, p. 94). Months later, Ingrid is "able to understand the people's mentality and decipher their behaviour" (LD, p. 49). Nevertheless, whenever she goes deeper below the surface, "she loses her way inside their compact heads, intelligent eyes and smiling mouths" yet she never gives up because she is secure in her belief that this is what Virgin Mary wants from her (LD, p. 50, 83). The narrator emphasises that Ingrid believes that "becoming one of them and so belief in her and consequently in Jesus would automatically pervade their hearts" (LD, p.83-4) despite the fact that she never reveals the truth about her mission. Nonetheless, Ingrid could not become part of the Yemini villagers' lives and identify with their particular ways while she remains in their eyes "as remote as a heroine from one of their folktales, or a princess imprisoned in a palace that no one could enter" (LD, p.54). So, Ingrid seems to be willing to desert the pleasures of her civilised world and daily life as Mahyoub describes them- "You will go home and turn on the hot tap, sleep with your head on a pillow, eat off your individual plate, drink milk and Pepsi from bottles" (LD, p.55-6)- for the beauty of the mountains, or what Ingrid claims to be an "earthly paradise", "the secure life" of Yemen, and "peace of mind existed in these half-empty houses, which contained only mattresses to sleep on, dishes to eat off, a toilet, a lamp. This was paradise" (LD, p.55). Ingrid prefers such a simple yet primitive life because, she claims, it takes her away from "outer and inner turmoil and moral decay" (LD, p.55). While Ingrid envies the villagers their happy life, Mahyoub objects, "What's the point of being in paradise if you don't have enough to eat?" (LD, p. 55). In Ingrid's so called paradise, Mahyoub comments bitterly, "mosquitoes and bilharzia worms run riot and qat dries up the mothers' milk" (LD, p.56). Are readers expected to appreciate Ingrid's Abandonment of modern civilisation and never question her true intentions? Early in narrative, we are told that Ingrid "did not have a special interest in [Mahyoub], but she had taken it upon herself to hand out advice to the villagers who had adopted her" (LD, p.53). In my opinion, the dream of a mutual understanding proves to be an inadequate and unrealistic response in such a primitive context. The hints towards the end of the story that Ingrid wishes to become part of Yemen and its people reflect her desire to belong to the place, i.e., to the land of the Other. Such a desire reflects a process which Terry Goldie (1989) calls "indigenization"; a word that suggests the necessity of becoming indigenous or native thus adopting the culture of the Other (Goldie, 1989, p. 234). The narrator tells us that Ingrid allows the Yemini village to "change her from a European woman into one who wore Yemini clothes, baked bread on an outdoor clay oven, spoke Arabic and hennaed her hand" (LD, p. 48). Such a perfect image of adjustment and assimilation is surely exaggerated!

\section{F. Hanan Al Shaykh: A Muslim and Arab Writer}

Sadly enough, Al Sheikh's depiction of the poor life of the Yemin people points out her despise of her national and native Arab culture and identity. Like her Yemini hero, she finds a safe refuge in the European world represented by Ingrid. Al Shaykh's position as a Muslim and an Arab writer living in Britain has shaped and dictated the themes and meanings of her fiction. Hanan Al Shaykh fails as an interpreter of Islamic Arabic experience. Her fiction is an articulation of her rejection of her native identity which justifies her felt need to engage with the demands of her new European environment. This environment contradicts the private world of her subjective experience as a Muslim, a Lebanese Shi'a, who grew up in Lebanon in a strict family and inside the highly conservative society of South Lebanon. 
Al Shaykh distorts the image of the Other rather than representing it faithfully. Consequently, her work must be read as her own personal statement rather than a reflection of the agonies of the Arab society. As an Arab writer, Al Shaykh's task should have been raising the consciousness of the Self (European and Western readers). Unfortunately, she is caught in a split position as she draws attention to the inferiority of her native culture and the superiority of European thought. The complex responses to the imperatives of her position, which make her work problematic, are the result of her struggle to connect with a new civilised environment and to separate herself from aspects of her native origin. Al Shaykh's dissatisfaction with the kind of life to which she was born has stimulated much of her fiction.

\section{CONCLUSION}

To conclude, the complexity of judging Al Shaykh's work stems from the fact no matter how dedicated to portrayal of the agonies of the Muslim and Arab women and men, she remains to some degree an outsider who has welcomed and embraced the culture of the Self. Her work is heavily influenced by the patriarchal controls that were placed on her not only by her father and brother, but also within the traditional neighborhood in which she was raised. No matter how sympathetic she is to the individuals of her own native world, she fails to introduce a faithful outlook of their life. In fact, Al Shaykh's confidence about her ability to write about any character is subject to doubt. In an interview with Christiane Schlote (2003), Al Shaykh claims that "at the beginning, you know, you usually concentrate on certain feelings you feel about things and then slowly, slowly, you start importing or inhabiting the soul of the characters. You can write about any character. It doesn't have to be something you experienced or something you felt a great deal about." In fact, Al Shaykh's ability to write convincingly about the life of the Yemini people is questionable. She fails in achieving the integrity which Chekhov demands "to describe a situation truthfully...that the reader can no longer evade it" (qtd. In Gordimer, 1989, p. 229).

I hope that this paper will inspire further questions and new horizons of discussion: Does Al Shaykh put her genuine identity under erasure for a better reception in the book market? Is she seeking attention and commercial success outside the Arab World because like many Arab female writers she has faced the same problems of reception? It is worth mentioning that some of AL Shaykh's works were banned3 in the more conservative areas of the region including the Arabian Gulf. So, is Al Shaykh a victim of Arab censorship? Amal Amireh (1996) sums up the issue: "The West welcomes her critique of Arab culture because it confirms the existing stereotypes of Arabs and Muslims as backward, misogynist, and violently oppressive. Thus, she confirms the ready-made assumptions and prejudices the Western and European readers have about the Arab World. Her promotion is part of the systematic and historical Euro-American demotion of Arabs and their culture".

\section{REFERENCES}

[1] Achebe, Chinua. (1973). Named for Victoria, Queen of England. New Letters 40.3, 15-22.

[2] Amireh, Amal (1996). You are here: Publishing in the West: Problems and Prospects for Arab Women Writers. Al Jadid. 2.10, August. http://www.aljadid.com/content/publishing-west-problems-and-prospects-arab-women-writers Accessed on 29/12/2017.

[3] Bhabha, Homi K. (1985). Sign Taken for Wonders: Questions of Ambivalence and Authority Under a Tree Outside Delhi. Critical Inquiry 12.3, 144-65.

[4] Fanon, Frantz. (1961). The Wretched of the Earth. Harmondsworth: Penguin.

[5] Goldie, Terry. (1989). Fear and Temptation: The Image of the Indigene in Canadian, Australian and New Zealand Literatures. Kingston: McGill-Queens UP.

[6] Gordimer, Nadine. (1989). The Essential Gesture: Writing, Politics, and Places. Stephen Clingman, ed. London, Penguin Books.

[7] Gyatri Spivak. (1988). Can the Subaltern speak?. Cary Nelson and Lawrence Grossberg eds. Maxims and the Interpretation of Culture. London: Macmillan.

[8] JanMohamed, Abdul R. (1985). The Economy of Manichean Allegory: The Function of Racial Difference in Colonialist Literature. Critical Inquiry 12.1, 59-87.

[9] Schlote, Christiane. (2003). 'An Interview with Hanan al-Shaykh'. Literary London: Interdisciplinary Studies in the Representation of London. 1.2, September. http://www.literarylondon.org/london-journal/september2003/schlote.html. Accessed on 29/12/2017.

Sura Khrais, $\mathrm{PhD}$, is an associate professor of English literature at Al Balqa Applied University, Amman, Jordan.

She is a freelance translator at KALIMA Translation Project which is part of the National Library Program Management Department of Abu Dhabi Tourism \& Culture Authority. She has presented at numerous professional conferences, is the author of

\footnotetext{
${ }^{3}$ For instance, The Story of Zahra was turned down by nine publishers in Beirut, then the centre of the Arab publishing world. Her work often implies or states sexually explicit scenes and sexual situations which go directly against the social norms of conservative Arab society, which has led to her books being banned. See, Amal Amireh (1996).
} 
Somewhere Where We Can Meet: The Representation of Place and Cross-racial Relationships in Nadine Gordimer's Novels. She has published many articles in the field of literature and literary translation.

Hana Daana, $\mathrm{PhD}$, is an assistant professor in the Department of English Language and Literature in Princess Alia University College/Al Balqa Applied University in Jordan.

She received her PhD in Language Acquisition from Essex University in the United Kingdom in (2009). She teaches courses such as: Language Acquisition, English Syntax, English Phonetics and Phonology, Semantics, Sociolinguistics, and Psycholinguistics. Her research interests are in the field of First Language Acquisition and Arabic Dialectal Differences. She has published many articles in these two fields. 